\title{
Introduction: the development of Global Administrative Law*
}

\author{
Sabino Cassese with Elisa D'Alterio
}

\section{THE DIMENSIONS OF GLOBAL ADMINISTRATIVE LAW}

In administrative law's two hundred years of history, the most important change has been the development of Global Administrative Law (or GAL, through the inception of 2,000 global regulatory regimes, 60,000 international non-governmental organizations, over 100 international courts, and a similar number of quasi-judicial bodies - as against 'only' 193 States). GAL is partly linked to the State, and partly connected with global institutions. ${ }^{1}$

Until a few decades ago, both administrative systems and administrative law developed in the specific context of the nation State. The legal environment that fostered the development of administrative systems and administrative law was a national government, which was run by a political body called the 'State'. Public administrations were conceived of as belonging to national communities, and as being structurally dependent upon national governments. Administrative law was thus fundamentally State law.

As a consequence, an exclusive link was established between the State and the administration, the best expression of which is the famous formula 'the administrative State', coined in 1948 by the US political scientist Dwight Waldo. ${ }^{2}$ Where there is a State, there is an administrative system - and vice versa. Administrative systems and administrative law were shaped according to the needs of the different State models; as each national State developed along divergent lines, administrative systems diverged too. Therefore, public administrations and their respective systems of administrative law became the ultimate enclaves of nationalism.

The development of global regulators and of global rules altered this traditional picture: State administrative law was monistic, while GAL has a dualistic dimension. State administrative systems diverge, while GAL has some unitary features and drives national administrative systems towards convergence.

As noted above, GAL has a double relationship - one with national governments, and one with global regulatory regimes. However, contrary to a commonly held

* The editor thanks Sarah Pasetto for her excellent editorial work throughout the volume.

1 Sabino Cassese, 'Il diritto amministrativo europeo presenta caratteri originali?', in Sabino Cassese, Il diritto amministrativo: storia e prospettive (Giuffrè 2010) 388-389. With regard to the number of international judicial bodies, see Cesare PR Romano (director), The Project on International Courts and Tribunals. The International Judiciary in Context (New York University Center on International Cooperation 2004), which distinguishes between existing, extinct, aborted, dormant, nascent, and proposed international judicial bodies, including quasi-judicial, implementation control and other dispute settlement bodies.

2 Dwight Waldo, The Administrative State: A Study of the Political Theory of American Public Administration (Ronald Press Company 1948; revised edn Holmes \& Meier 1984). 


\section{Research handbook on Global Administrative Law}

opinion, GAL is not a layer of regulation that is superimposed upon State regulation, and administrative law is not a multi-level system, because global regulation percolates into national legal orders and the result is a mixture of national and global measures.

Consequently, in the global perspective, the concept of publicness is also subject to change, because it is influenced by the State in connection with global regulators. The State remains the protagonist, but new actors play the part of deuteragonist (or vice versa).

As a result of this overlap between the State and supranational rulers and rules, the divergence of administrative systems and of national administrative legal systems is limited by a body of basic common rules - shared among the various global regulatory regimes - with which all members of the international community are expected to comply.

A second problem for the field's identity is the use of the adjective 'global' rather than 'international'. Historically, the latter term was used with reference to inter-State relations, assuming the paradigm of the State as a unit, while 'global' also refers to civil societies and to the fragmented State. ${ }^{3}$ GAL captures three dimensions: civil societies (and not only national rulers and ruling bodies); national institutions (but not as part of a unitary legal person); and supranational, international and transnational institutions. From this perspective, GAL is characterized not only by a 'trilateral' relationship (between civil societies, national institutions and institutions beyond the State), but also by the emergence of 'new alliances': as local and global interests converge, global institutions establish alliances with individuals or national civil societies against States. ${ }^{4}$ For example, the regimes for the protection of the global environment or cultural heritage use civil society members as 'fire alarms' against the action of national governments. Choosing the term 'global' instead of 'international' is not, therefore, a matter of mere terminology, because the former refers to the world as an interconnected whole. ${ }^{5}$

3 According to Mark Mazower, Jeremy Bentham, who coined the word 'international', sought to stress two points: the need for a sharp distinction between the law within a State and the law between States, and the distinction between the legal disputes affecting individuals and those affecting sovereign States: see Mark Mazower, Governing the World. The History of an Idea, 1815 to the Present (Penguin 2013) 20.

4 The development of global regimes is closely linked to the aim of verifying national systems' compliance with the relevant guarantees provided in favour of individuals (as emphasized by Stefano Battini, 'L'impatto della globalizzazione sulla pubblica amministrazione e sul diritto amministrativo: quattro percorsi' (2006) Giornale di diritto amministrativo 341).

5 On GAL in general, see Benedict Kingsbury, Nico Krisch and Richard B Stewart, 'The Emergence of Global Administrative Law' (2005) 68(3-4) Law and Contemporary Problems 20; Eleanor D Kinney, 'The Emerging Field of International Administrative Law: Its Content and Potential' (2002) 54(1) Administrative Law Review 415; Bhupinder S Chimni, 'Co-Option and Resistance: Two Faces of Global Administrative Law' (2005) 37(4) Journal of International Law and Politics 799; Carol Harlow, 'Global Administrative Law: The Quest for Principles and Values' (2006) 17(1) European Journal of International Law 187; Armin von Bogdandy, Rüdiger Wolfrum, Jochen von Bernstorff, Philipp Dann and Matthias Goldmann (eds), The Exercise of Public Authority by International Institutions: Advancing International Institutional Law (Springer 2009); Benedict Kingsbury, 'The Concept of "Law" in Global Administrative Law' (2009) 20(1) European Journal of International Law 23; Benedict Kingsbury and Lorenzo 


\section{ADMINISTRATION WITHOUT A CONSTITUTION?}

One of GAL's peculiarities is the fact that it is much more developed than its constitutional foundations. The latter are limited to a body of basic human rights, and there is no global government. Conversely, GAL comprises a large number of global rules and regulators, which basically reproduce the organizational styles and procedural paradigms that are well known within States, such as the right to a hearing, the duty to provide reasons, judicial review, and the due process of law generally. Therefore, the world is more united by global administrative standards than constitutional principles; by the regulation of trade and the environment, more than by law and order or defence; and by the global definition of matters of low politics, rather than of those pertaining to high politics. This peculiarity differentiates GAL from national administrative law, which is instead subject to a process of constitutionalization and is fundamentally ruled by constitutional principles.

Another peculiarity derives from the absence of a single government and of a single comprehensive legal order at the global level. In the global space, several global regulatory regimes act without subjection to one hierarchically superior regulatory system. This is the empire of the 'adhocracy', because there is no uniformity and no common pattern. This fragmentation is balanced in various ways: links form between otherwise self-contained regimes, cross-references are made between area regulations, the use of 'precedents' taken from different regulatory regimes diffuses, and so on. ${ }^{6}$

However, a process of convergence of the different regulatory regimes is under way, as

norms, standards and expectations that have crystallized in most domestic legal systems have migrated to global governance bodies and now frame perceptions about the legitimacy of their decision-making processes and decisions. At the same time, this process of migration creates pressure for convergence, in what sociologists would call a process of isomorphism. ${ }^{7}$

Also, '... the substantive norms of administrative law ... are generally similar in most domestic and global systems, and are certainly undergoing a process of assimilation $\ldots . .8$

Casini, 'Global Administrative Law Dimensions of International Organizations Law', in Laurence Boisson de Chazournes, Lorenzo Casini and Benedict Kingsbury, Symposium on 'Global Administrative Law in the Operations of International Organizations' (2009) 6(2) International Organizations Law Review 326, n 23, 319. In the French literature, see also Jean-Louis Halperin, Profils des mondialisations du droit (Dalloz 2009) (who traces the history of legal globalization from Roman law to constitutionalism and codification), but mainly Jean-Bernard Auby, $L a$ globalisation, le droit et l'Etat (2nd edn, LGDJ 2010). In the Italian literature, see Maria Rosaria Ferrarese, Diritto sconfinato. Inventiva giuridica e spazi nel mondo globale (Laterza 2006) and Sabino Cassese, Il diritto globale (Einaudi 2009).

6 Sabino Cassese, The Global Polity. Global Dimensions of Democracy and the Rule of Law (Editorial Derecho Global/Global Law Press 2014) 22 ff.

7 Eyal Benvenisti, The Law of Global Governance (Brill/Nijhoff 2014) 195.

8 Ibid 196. 


\section{Research handbook on Global Administrative Law}

In conclusion, while GAL largely includes national administrative legal orders, it remains significantly different from the administrative laws developed within national governments.

\section{THE 'MARBLED' STRUCTURE OF GLOBAL ADMINISTRATION: THE ROLE OF GLOBAL REGULATORY REGIMES}

The American political scientist and diplomat Henry Kissinger has written that:

The contemporary, now global Westphalian system - what colloquially is called the world community - has striven to curtail the anarchical nature of the world with an extensive network of international legal and organizational structures designed to foster open trade and a stable international financial system, establish accepted principles of resolving international disputes, and set limits on the conduct of wars when they do occur. This system of states now encompasses every culture and region. Its institutions have provided the neutral framework for the interactions of diverse societies - to a large extent independent of their respective values. ${ }^{9}$

The American historian Mark Mazower has observed that:

Today there is more global policymaking, in more varied form, than ever before ... There are military alliances, such as NATO and WEU; intergovernmental organizations in the classic mold, from the UN to specialist agencies such as the ILO, ICAO, ICC, WHO, and GATT; regional bodies, like the Council of Europe, the European Commission, and the Organizations of American and African states; post-imperial clubs, like the Commonwealth and the Organisation international de la Francophonie; quasi-polities like the European Union; and regular summit conferences like the G-20. Nor should one ignore the vast number of NGOs of all kinds, many of which now play a more or less formalized role in shaping global politics. ${ }^{10}$

He has also written that '[n]inety per cent of international NGOs have been formed since 1970, and there has been a quickening of associational life on a scale not seen since before the First World War: a 1994 Foreign Affairs article referred to a "Global Associational Revolution"". ${ }^{11}$

The American political scientist Anne-Marie Slaughter has written that:

There is an entire infrastructure of global governance that is not at the UN, or at the World Bank, or at the International Monetary Fund or at the World Trade Organization. It is the networks of antitrust officials, of police officials, prosecutors, financial regulators, intelligence operatives, militaries, judges and even, although lagging behind, legislators. ${ }^{12}$

9 Henry Kissinger, World Order. Reflections on the Character of Nations and the Course of History (Penguin 2014) 6.

10 Mazower (n 3) XVII.

11 Ibid 417.

12 Anne-Marie Slaughter, 'A New UN for the New Century' (2006) 74(6) Fordham Law Review 2961. 
Global regulatory regimes cover many fields:

forest preservation, the control of fishing, water regulation, environmental protection, standardization and food safety, financial and accounting standards, internet governance, pharmaceutical regulation, intellectual property protection, refugee protection, coffee and cocoa standards, labour standards, antitrust regulation, regulation and finance of public works, trade standards regulation of insurance, foreign investments, international terrorism, war and arms control, air and maritime navigation, postal services, telecommunications, nuclear energy and nuclear waste, money laundering, education, migration, law enforcement, sport, and health. ${ }^{13}$

Richard B. Stewart has classified global regulators into four basic types:

(1) formal treaty-based international or intergovernmental organizations (such as the WTO, the Security Council, the World Bank, and the United Nations Framework Convention on Climate Change regime); (2) transnational networks of domestic regulatory officials (such as the Basel Committee on Banking Supervision); (3) private regulatory bodies (such as international sports federations, the Society for Worldwide Interbank Financial Telecommunication, and the Forest Stewardship Council, constituted by non-state actors, including business firms, trade and professional associations, and NGOs); and (4) hybrid public-private regulatory bodies (such as the International Conference on Harmonisation of technical requirements for registration of Pharmaceuticals for Human Use, the World Anti-doping Agency, ICANN, and the Global Fund to Fight AIDS, Tuberculosis and Malaria (Global Fund)) - composed of non-state actors and international organizations and/or governments. ${ }^{14}$

The growth of global regulatory regimes is due to a variety of reasons: to statisticians, geographers, engineers, physicians who believed that the 'fundamental unity of the world was a scientific fact'; 15 to politicians for whom 'internationalism was preeminently a movement to restore sovereign power to the peoples of the world and those who governed in their name'; ${ }^{16}$ and to public administrators who acted as the architects of modern international organizations. ${ }^{17}$

13 Cassese (n 6) 20.

14 Richard B Stewart, 'Remedying Disregard in Global Regulatory Governance: Accountability, Participation, and Responsiveness' (2014) 108 American Journal of International Law 216.

15 Mazower (n 3) 95. See also Jürgen Renn (ed), The Globalization of Knowledge in History (2012) Max Planck Research Library for the History and Development of Knowledge, Studies 1 $<$ http://www.edition-open-access.de/studies/1/> accessed 5 June 2015.

16 Mazower (n 3) 421-422; see also 152-153. From a similar perspective, see Andreas L Paulus, 'Law and Politics in the Age of Globalisation' (2000) 11(2) European Journal of International Law 465.

17 Mazower (n 3) 155 ff; see also $281 \mathrm{ff}, 299$ ff, 317 ff, 359 ff. In the European context too, public administrators acted as architects of an ultra-State model of public administration 'whose area overlaps with the space of European Union, incorporating the effects of globalization': Ani I Matei and Lucica Matei, 'Globalization and Europeanization. A Projection on a European Model of Public Administration' (2007), paper presented at the 27th International Congress of Administrative Sciences, organized by the International Institute of Administrative Sciences in Abu Dhabi, United Arab Emirates, on 9-14 July 2007 (available at http://ssrn.com/abstract= 1310129). 


\section{Research handbook on Global Administrative Law}

Global regulatory regimes present many peculiar features. First, despite the rapid expansion of their material scope and the proliferation of regulators, they are still at an early stage of development and have not yet reached maturity. Legal scholars are therefore obliged to take into account the fact that their object of study is, as yet, in itinere.

Second, they are composite organizations, as they include global bodies, national authorities and personnel, representatives of civil society, transnational networks, members of epistemic communities, and various types of stakeholders, with no clear dividing line or hierarchy between the local and the global; in many ways, they can be compared to the European empires of the seventeenth to nineteenth centuries. ${ }^{18}$

Third, there is no unitary government and rule, but rather a multiplicity of diverse elements, which are fragmented and often not interconnected because there is no superior unifying authority (and no national legal system is currently willing to recognize a superior authority having general competences). This allows for a certain degree of flexibility and ability to adjust to different situations, but also leads to a lack of uniformity, coordination and planning; these drawbacks are compensated for by the establishment of links between global regulatory bodies and procedures. ${ }^{19}$

18 See Jörn Leonhard and Ulrike von Hirschhauser, Imperi e stati nazionali nell'Ottocento (Italian tr, Il Mulino 2014) 7-8.

19 Elsewhere, I have written:

National governments are unitary and have an executive body at their centre. In the global space there are several different regulatory regimes and there is no single executive. In national legal orders, a central executive is accompanied by a body of general rules, which is then divided into sector-specific norms. The former confer coherence and uniformity to the latter. At the global level, the situation is different. Almost all human activities are regulated by global norms. The latter are highly diverse. Some establish only framework legislation, for States to flesh out through regulatory activity; some provide guidelines for national authorities; others directly impose certain obligations upon private parties; other norms can rely on global authorities for implementation or to control implementation; some rely on national authorities for these activities; some provide instruments of judicial conflict resolution, while others yet are devoid of such mechanisms and resort only to negotiation or national judges. However, they do present a common trait, outlined above: these normative entities are all sector-based; there is no general set of rules (or meta-rules) to operate as a unifying element. The global legal space compensates for the disadvantages of this sectoralism in several ways. The first and most common course is a process of accretion and accumulation of legal principles, as highlighted by the first decision issued by the Arbitral Tribunal established by the Convention on the Law of the Sea. The second is the establishment of horizontal connections between different normative bodies. For example, the standards established by the Codex Alimentarius Commission were voluntary prior to 1995 , but have since acquired legal force because the WTO required parties not wishing to observe them to prove their capacity to guarantee an adequate level of protection. These connections are usually established starting from, and surrounding, the most important global normative bodies, such as that on trade, which, due to their scope, exert gravitational pull on other sector-based regulations. Thus, the various regulatory bodies are distinct but not separate. As established by the first decision issued by the Appellate Body of the WTO, the global laws on trade are not to be interpreted in isolation, separate from general international law. This gave rise to the ever-closer connections between rules on trade, on one hand, and those on environmental protection, worker protection standards etc. on the other. (Sabino Cassese, 
Fourth, there are no strong executives; global institutions lack enforcement powers, and in the great majority of cases rely upon nation States as enforcers. ${ }^{20}$ The absence of a centre is balanced by the presence of a great array of collegial bodies, in which parties of diverse nationalities meet to discuss, convince and reach compromises, similarly to the Spanish Empire's 'polisinodality'.

Fifth, since GAL features a double link - one with the State and one with global institutions - and the State's influence is weakened, the public-private divide is blurred and hybridism prevails (for example, in procedural matters, the WTO places national governments and private producers, exporters, importers, and interested parties all on an equal footing).

Sixth, due to the fact that global regulators are fragmented, and there is no single global hegemonic government, it is necessary to rule indirectly. Global regulators thus act as standard-setters and gatekeepers, and rely upon national authorities as implementers. In doing so, global regulators break away from the paradigm of the 'State as a unit', and establish direct links with the national bodies empowered to act in the relevant fields, often bypassing national executives and Parliaments.

Finally, in the relations between global and national bodies, the crucial point is that of enforcement. The former have experimented with several ways to enforce their decisions: by gaining support from below, i.e. civil society, which sounds a 'fire alarm' and pressures national authorities to enforce; by making it expedient to comply with decisions taken at the global level, through incentives and rewards; by sanctioning non-compliance with expulsion measures; by exploiting conflicting interests and introducing retaliatory measures under judicial control. However, despite all these indirect measures, the final word for enforcement still falls to national governments. This is advantageous in that it is reassuring for States, which can delegate powers to global bodies more easily; but it also has a cost, as enforcement is irregular and ultimately relies upon voluntary compliance.

\section{A DIFFERENT TYPE OF RULE OF LAW}

As noted above, the global space is replete with rules that impose transparency, as well as affirmations of the right of stakeholders to a hearing, the right to be informed and consulted, the duty to provide reasons, and the right to a judge and to the judicial review of decisions. Procedural rights are more broadly present in some contexts, and more limitedly in others.

'The Administrative State in Europe', in Ius Publicum Europaeum (Oxford University Press, forthcoming).)

20 For more details on enforcement mechanisms in the global administrative space, see Sabino Cassese, Elisa D'Alterio and Maurizia De Bellis, 'The Enforcement of Transnational Private Regulation: A Fictitious Oxymoron', in Fabrizio Cafaggi (ed), Enforcement of Transnational Regulation. Ensuring Compliance in a Global World (Edward Elgar Publishing 2012) $331 \mathrm{ff}$. 


\section{Research handbook on Global Administrative Law}

One of the most striking features of the global legal space is the speed at which principles of the rule of law have developed within the different legal orders. ${ }^{21}$ Institutions that took decades or even centuries to develop within States quickly expanded beyond the State, sometimes even more proficiently than in the State context. It is likely that the reason for this rapidity lies in the fact that all States have experienced a historical phase of absolutism, during which the principle of authority prevailed and no administrative rights were granted to citizens. It took centuries for certain basic rights to be recognized against the executive agencies of national governments.

The global context exemplifies the influence of American institutions and culture, as most of its rules follow the model of the 1946 US Administrative Procedure Act. However, the due process clauses of the global space do not have the same structure and function as those of their national counterparts.

First, these clauses are provided by global rules, but are imposed upon national authorities, not upon global regulators. They endow nationals with additional rights vis-à-vis national governments, rights that are not provided by national law. Paradoxically, global rules are less generous in providing people with access to and a voice against global institutions; hence the observation made by certain scholars that global regimes 'operate in an essentially closed and opaque manner' ${ }^{22}$

Second, these procedural requirements play a different role also from a functional point of view. They act as fire alarms: global bodies cannot patrol the whole world to ensure compliance on the part of national governments, and must therefore rely upon information from nationals, individuals or associations. Thus, they also act as an instrument for mobilization and integration. Global bodies grant access to citizens, whose participation is not allowed by national law, and foster strategic alliances between global institutions and civil societies against national governments. In the meantime, they level the playing field, diffusing certain basic administrative rights throughout the world or within supranational regions, and opening the path to dialogue.

In giving citizens a voice and imposing upon national authorities an obligation to openness and to give reasons, due process clauses also perform a legitimating role for the global bodies that act as guarantors of civic rights. The expanding role of global rules and bodies as guarantors may, one day, become a weak surrogate for global democracy.

One may conclude that due process principles, when transplanted into the global space, become different from the analogous procedural rights established by national rules against national authorities - that they are not new, but rather become different in a new context.

Similar conclusions can be traced for reviewing mechanisms. Not all 2,000 global regulatory regimes provide such mechanisms; however, some 10-15 per cent do have

21 Jorge Agudo Gonzalez, 'The Evolution of Administrative Procedure Theory in "New Governance" Key Point' (2013) 6(1) Review of European Administrative Law 73.

22 With regard to the WTO, see Richard B Stewart and Michelle Ratton Sanchez Badin, 'The World Trade Organization: Multiple Dimensions of Global Administrative Law' (2011) 9(3-4) International Journal of Constitutional Law 556. 
either courts, tribunals, panels, compliance committees, inspections panels, or assessment panels. ${ }^{23}$

The reviewing bodies established at the global level are affected by four problems. First, they are called upon mainly to review decisions taken by national authorities, and not decisions taken by global institutions. They are therefore instrumental to global regulators' control of national bodies' compliance with global standards. They trigger an alarm system through popular participation (complaints), legitimate global rules and maximize the power of global regulators. They also raise a question that is much debated in the United States: since national governments accept becoming party to treaties establishing global regulatory regimes, and thus acquire an obligation to comply with global standards, could not national courts be in a better position to provide such review?

Second, the review bodies act in a space that is not entirely developed as a unitary entity that adopts the parameter of legal reasonableness, appearing to prefer more flexible standards such as suitability, appropriateness or expediency, or even simply technical standards (e.g. the International Civil Aviation Organization's Universal Security Audit Programme Continuous Monitoring Approach). This integration of review standards raises many questions. Are the members of the reviewing bodies the most suitable parties to evaluate such a broad scope of standards? Are adversarial procedures appropriate to these evaluations? Could it be more appropriate to delegate these evaluations (which examine the merits of decisions subject to review) to independent and non-accountable bodies?

Third, this type of review is not only reactive, but is often proactive. Reviewing bodies are also required to make proposals, to direct training to ensure compliance in the future, and to make suggestions.

Fourth, while reviewing bodies must adjudicate, they either have no or only primitive rules of procedure. Certain bodies adopt reviewing procedures on a case-by-case basis. Many reviewing bodies require national authorities to ensure transparency, openness and participation, but are themselves neither transparent nor open, and do not provide full hearings.

Finally, the decisions taken by reviewing bodies are necessarily limited to the specific field in relation to which the rules are enacted. However, many of these tribunals and quasi-judicial bodies make reference to decisions taken by reviewing bodies acting in other regulatory regimes; they therefore establish bridges with one another, and contribute to the defragmentation of the global space and the development of certain common jurisprudential principles. In so doing, they act as promoters, developers, accelerators and system builders of a global legal order.

23 Mazower (n 3) $397 \mathrm{ff}$ and 402 ff; and Sabino Cassese, When Legal Orders Collide: The Role of Courts (Editorial Derecho Global/Global Law Press 2010). See also Cesare PR Romano, 'A Taxonomy of International Rule of Law Institutions' (2011) 2(1) Journal of International Dispute Settlement 252. 


\section{DEVELOPMENT MECHANISMS}

GAL has developed rapidly, but in an incremental and even accidental fashion. Its development has been rapid, taking place in the space of only 20-30 years; incremental and accidental, because it has grown without a prior plan or a design, prompted by two types of pressures. First, governments are challenged by new problems that are of a global scale and thus require global solutions: global warming, global terrorism, the organization of the Olympic Games, the disposal of nuclear waste, the financial crisis. Second, local problems now become global: local environmental associations require UNESCO's assistance to protect sites that are registered as world heritage sites (e.g. Yellowstone National Park in the United States); and national governments ask the UN for advice and support in prosecuting crimes (e.g. the case of Guatemala).

Under these pressures, global rules, institutions and procedures have developed under the strong influence of American examples - not necessarily as part of a process of 'colonization', but mainly as a process of contamination and intellectual influence.

This process of development is necessarily incomplete and therefore presents several black and grey holes. It has begun at the edges, and is slowly moving towards the centre. However, it is not ephemeral, nor will it disappear. A new constitution will eventually emerge from this fabric of administrative law, reversing the trend in national governments according to which administrative law has usually developed on the basis of a stable constitution, growing out of constitutional law.

\section{THE STUDY OF GLOBAL ADMINISTRATIVE LAW}

The study of GAL must overcome two important difficulties. One relates to ideological prejudices, approaches and biases. The second concerns traditional legal scholarship.

The first danger is that of becoming imprisoned in one of two opposing points of view, one optimistic and one pessimistic. The optimist finds, in globalization, the solution to all of the world's social and economic problems. The pessimist finds that globalization is either not relevant or even dangerous.

The second danger, instead, is of remaining enslaved to the nationalistic approach developed by legal positivism: States are monopolistic law-makers, the subject of legal scholarship is the law, and therefore lawyers are always bound to study State law. This approach - defined by Raymond Saleilles as one of 'nationalisme étroit' - has suffocated the research of more general laws that transcend the State. On this view, openings to other legal systems have been accepted only in terms of legal comparison, and not as the study of transplants, circulation, dialogue, hybridism, convergence, or common core principles.

All these developments are not entirely new: Jeremy Bentham (1748-1832) already distinguished local and universal forms of jurisprudence; Giandomenico Romagnosi wrote a book on 'Diritto pubblico universale' ('Universal public law', 1833) and 
Raymond Saleilles wrote that 'toute science juridique est forcément internationale et universelle' ('all juridical science is necessarily international and universal', 1904). ${ }^{24}$

\section{ABOUT THE HANDBOOK ${ }^{25}$}

The structure of this Handbook follows a specific order, which gradually shifts from a 'horizontal' to a 'vertical' perspective. According to the former, the Handbook considers the growth of 'global administrations' (Chapters 1-5), their interactions through the creation of 'global networks' (Chapters 6 and 7), the emergence of a 'global administrative process' (Chapters 8-11), and the development of the rule of law and democratic principles at global level (Chapters 12-16). From the latter, the relations between global law and other legal orders are examined, with particular attention being paid to regional systems (the EU, the Global South, and the global law of development - Chapters 17-19) as well as national orders (Chapters 20-23). The final section, devoted to the emergence of a 'global legal culture', closes the circle by recognizing the growth of an epistemic community at the global level (Chapters 24-26).

The development of Global Administrative Law (GAL) studies is connected, first, with the gradual expansion of global law, and more precisely of its 'material scope' (Casini, Chapter 1). Over the last few decades, an 'irresistible rise of rules, institutions, and regimes' has characterized the global space, by affecting several different sectors (trade, finance, protection of human rights, and global public goods) to pursue collective interests of the world ('drivers of global law's development'): global rules and institutions are aimed at leading and controlling states' exercise of powers, by better ensuring the effectiveness of legal measures (especially through 'hybridization', as demonstrated by the World Anti-Doping Code case). Four main dimensions (regulatory, (quasi-)judicial, institutional, and procedural) contribute to the "process of development': the number of global norms, the increasing significance of the role played by global (quasi-)judicial bodies, and the rise of supranational bureaucracies and global procedures are the most significant examples of this trend. Connections between the 'drivers' and 'dimensions' analysed enable the identification of patterns of legal globalization at the basis of GAL.

Indeed, the emergence of 'global administrative regulation', developed 'within an extraordinary multitude and variety of "global regulatory regimes", is a key feature of GAL (Battini, Chapter 2). There are approximately 2,000 global regulatory regimes, which perform increasing regulatory functions (an example is the growing number of ISO standards, which rose from 6,401 in 1986 to 19,573 at the end of 2012) and assume a variety of different forms (intergovernmental or transgovernmental regulatory networks; formal international organizations; hybrid public/private or private institutions, etc.). Their general role aims to fill effectiveness and, mainly, 'external

24 Raymond Saleilles, 'Le Code civil et la Méthode historique', in 'Le Code Civil 1804-1904' Livre du Centenaire publié par la Societé d'Etudes Législatives tome premier (Librairie Edouard Duchemin 1904, reprinted 1969) 127, author's translation.

25 This section by Elisa D'Alterio. 


\section{Research handbook on Global Administrative Law}

accountability' gaps: states are not accountable to other states affected by their domestic regulation. Therefore, global regimes reduce these gaps by promoting the horizontal and vertical integration of domestic regulatory systems, respectively by imposing the duty to take outsiders' interests into account, and requiring national regulators to jointly exercise their right to regulate. Nevertheless, the fragmentation of the global institutional landscape and the accountability deficit affecting global regimes constitute relevant 'pitfalls' of GAL.

An important branch of global administrative regulation corresponds to global rules that govern the relationship between global regimes and their employees - traditionally labelled 'international administrative law' (Villalpando, Chapter 3). The basic features of the international civil service system are the internal structure of regulation (including the organization's constituent act, staff regulations and rules, administrative issuances, etc.) and the mechanisms that ensure adequate participation on the part of the rules' recipients. Nevertheless, the relationship between this regulatory regime and the international legal order (are these two separate orders?) and the legal nature of the relationships that it governs (are these contractual relationships?) are far from clear. International administrative tribunals play a key role in applying the above-mentioned rules, by judging cases of alleged breach of the terms of appointment and conditions of employment of the organization's staff members. Although these rules constitute 'an assorted landscape' (which is closely affected by the size of the organization's personnel, the types of disputes involved, the relations between the management and the staff, etc.), a common need to guarantee the highest standards of transparency, participation, reasoned decision and review emerges. From this perspective, 'International Administrative Law constitutes ... a fertile field for the implementation of the principles of GAL'.

Another significant branch of global administrative regulation regards public procurement (Morlino, Chapter 4). Legal globalization leads to 'a new and inclusive concept of international public procurement that encompasses various procedural models and peculiar interplays of interests'. In particular, a new balance of interests takes place: the 'prioritarization' of the public interest represented by domestic administrations is better balanced with the need to safeguard private economic actors. The emergence of these 'new actors' contributes, in turn, to the growth of a number of regulatory and integrated frameworks (based on international and regional agreements; global procurement guidelines for procurement carried out by states within projects financed by the organizations; procurement rules of international organizations; and general conventions and model laws on public procurement), which include - more or less effective - transparency, publicity and accountability rules, depending on the global regime under consideration (World Trade Organization (WTO), UN, World Bank (WB), etc.). Thus, private subjects can now claim more guarantees vis-à-vis national administrations. Nevertheless, states remain the ultimate regulatory arbitrators, by influencing rules and procedures that are applied at the global level, sometimes even in favour of companies incorporated in their jurisdiction.

The analysis of GAL prompts questions as to its constitutional foundations (Möllers, Chapter 5). The main assumption is that GAL is rarely founded on constitutional standards, but is rather the result of intergovernmental politics and technocratic inter-administrative coordination'. In particular, the application of 'traditional' rule of 
law principles in the global space is greatly 'mitigated'. For example, in relation to the principle of publicity, there is a tendency in various fields of international and transnational law to 'conceal' the rules (as in anti-terrorism policy); moreover, foreign affairs almost always enjoy less democratic legitimation than domestic decisions, because they are under less intense judicial review as well as under relatively weak parliamentary control. Even in relation to the protection of human rights, 'typical structural obstacles' emerge. Nevertheless, some remedies attempt to fill these gaps: administrative cooperation between states, the development of multilevel relations, the legal formalization of global structures, the promotion of domestic democracy by means of international law, etc. Therefore, some typical practices of international administrations may be reviewed from a different perspective, and hardly correspond to a 'positive constitutional foundation' for GAL.

With regard to multilevel relations, a common feature of global administrative regulation is the existence of linkages established by international governmental organizations (IGOs) among themselves as well as with non-governmental organizations (NGOs) and other civil society organizations (CSOs) (Savino, Chapter 6). First, relevant linkages are consultative practices (such as the "consultative-observer status' and non-decisional participatory rights to civil society, in IGOs). Second, 'transgovernmental polysynody' (state administrations cooperating with their counterparts) and 'supranational polysynody' (secretariats liaising with their neighbours by establishing mixed coordinating groups) are significant forms of 'coordination' that differ from 'joint ventures' due to the much stronger linkage that characterizes the latter model, which is based on 'programmatic alliances', perhaps even by establishing a new IGO. Finally, 'orchestration' occurs when IGOs establish synergies with other non-state actors to overcome their own implementation deficit in national systems. This composite set of linkages reveals a 'proactive strategy' on part of IGOs, which are becoming less state centric and more connected to a 'new real world order', within which the practices of establishing linkages and allowing civil society's participation in international decision making can, after all, constitute democracy-enhancing tools.

The relations among global regimes may also assume the form of 'networks' and 'shared administrations' (Craig, Chapter 7). Global networks perform different functions and - as recalled in Slaughter's studies, cited - 'can improve compliance with international rules and increase international cooperation'; in turn, these networks can operate 'by and through shared administration' with authorities at the national or regional level. Relevant examples are the WTO and ISO systems: despite some differences, these models are characterized by significant practical and normative consequences for administrative law in terms of input legitimacy (in relation, respectively, to the effects of treaties and to normative enforcement), transparency (with regard to concerns relating to the dispute settlement process and to standard-making process, respectively), judicial review (on the one hand, is it adequate? On the other, is it fairly uniform?) and regulation (by expanding markets and spurring regulation, and by promoting interactions). In any case, the application of the rule of law in such global contexts encounters several challenges, due to the negative effects 'in any sphere where international law (broadly conceived) impacts on national law'. Therefore, initiatives aimed at securing rule-making accountability with a 'multilevel approach' - such as 
those promoted in the US by President Obama's government or, a decade earlier, by the American Bar Association - should be welcomed.

All the above-mentioned global regulatory bodies generate myriad regulatory norms (specific rules and standards of conduct, procedural and institutional requirements, indicators and rankings, etc.), which are implemented by national administrations (Stewart, Chapter 8). There exist different forms of implementation: for instance, many intergovernmental bodies rely upon their members' national administrative agencies as 'distributed administration'; conversely, private and hybrid bodies use different types of distributed administrations to implement their regulatory programmes, in many cases even without the intermediation of national authorities. Economic or security benefits, strategic institutional considerations, etc. are only a few examples of the incentives for national administrations to implement global regulatory norms, although the implementation may be limited by political factors and local contestations and resistance. From this perspective, a principal-agent analysis enables us to identify some strategies to deal with this challenge: in particular, GAL procedures for transparency, participation, reason-giving and review enable the beneficiaries of global regulatory norms to track and promote compliance by domestic administrations. Nevertheless, problems concerning the accountability of global regulators to domestic publics, and vice versa, persist.

Global administrative regulation is also largely based on 'negotiation': indeed, 'negotiation has been at the core of international legal processes' (Wouters, Chapter 9). More precisely, negotiation can be considered an essential tool, first of all for peace-making: timing, place and a methodology based on mediation are the main features. Second, it is a basic tool for treaty-making, which remains an important mode of entering into legally binding commitments in international relations, whether in a bilateral or multilateral context. A third model is decision-making in international organizations, which is the highest institutionalized form of negotiation. The calculation of votes in decision-making may vary, depending on whether a majority, consensus or unanimity scheme is chosen, with different criteria (such as the conferral principle) and negotiation dynamics, as in the case of the UN Security Council. Another model is standard-setting: this form of negotiation is mainly characterized by "voluntary sustainability standards' (VSS), based on a very detailed and inclusive process. Finally, negotiation is an important part of international dispute settlement: hence the assumption whereby granting direct effect to a WTO provision over EU rules would deprive contracting parties of the possibility of resorting to negotiation as a main tool to resolve the dispute.

Another peculiar form of global regulation is transnational private regulation (TPR) (Cafaggi, Chapter 10). Several private regimes operate in the global arena, with 'varying densities of the spaces in which they act': more precisely, they may operate in a monopolistic or oligopolistic framework or, conversely, in more competitive contexts. In the former cases, the legitimacy, efficiency and effectiveness of the regulatory process are challenged. Nevertheless, in the latter cases too, the fragmentation of global private regimes contributes to 'complexity, which can increase search and management costs without necessarily expanding the choices available to regulated entities', by increasing conflicts and inefficient regulatory competition. The main responses to the proliferation of private schemes have been both regulatory convergence at the global 
level, especially through 'orchestration by public organizations', and the emergence of 'private meta-regulators'. A relevant distinction is that between organizations that are based on membership and those that are not, with more specific differences related to the design of the relationship between the meta-regulator and the regulated, what is regulated, etc. TPR is mainly sector-specific, but meta-regulators increasingly aim to provide common principles across sectors, thus gradually contributing to the development of a 'cross-sectoral meta-regulation'.

Global administrative regulation can be enforced by means of different procedures, which must be analysed (Marchetti, Chapter 11). In the past, enforcement was performed unilaterally by the state affected by the breach; since 1945, instead, only economic and commercial countermeasures have been permitted (retaliatory measures), and must be preceded by an attempt at mediation, with the increasing involvement of judges, conciliators and civil society. Today, the main consequence of states' illegal conduct is 'outcasting', which may be preceded by an adjudication procedure carried out by ad hoc tribunals (a 'combination of legal and negotiational measures'). Moreover, Member States, authorized by global institutions, can ensure the enforcement of global rules, for example when national courts are called upon to enforce global norms, or these rules are incorporated into state law. The application of the above-mentioned mechanisms often depends on the degree of juridification of the global regime; in turn, the effectiveness of each enforcement mechanism may depend on voluntary compliance, or on the costs of non-compliance, in political, economic and reputational terms. Nevertheless, "the question of enforcement remains largely powerbased, due to the difficulties of reconciling coercive powers with State sovereignty'. The political and diplomatic dimension, indeed, remains the true leader of all enforcement mechanisms.

GAL affects individuals, citizens and enterprises: hence the need for guarantees to protect these parties against improper or arbitrary use of power, by promoting the rule of law at the global level (Macchia, Chapter 12). In the global space, the 'first purpose' of the rule of law is to restrain the power of global institutions and the 'second purpose' is to bind the legislative and administrative powers of states from the outside. Nevertheless, in this context, the rule of law cannot be considered a principle of democratic legitimation, but is rather 'a prerequisite for the protection of fundamental rights'. In turn, many global regimes limit the power of national authorities, by imposing specific standards on the basis of a 'proceduralization' of substantive obligations contained in international treaties or secondary legislation. The global rule of law is also measured by means of specific indicators, such as the Rule of Law Index in The World Justice Project. Cooperation among states and some international development projects are relevant tools in promoting the rule of law in the global space, although several difficulties emerge (such as those relating to the legitimacy of global institutions). In this sense, the theory of 'trusteeship obligations' may be a persuasive answer: the fiduciary relationship between global institutions and civil society should compel institutions fulfilling a public function to act with a view to the public interest.

The enforcement of the global rule of law is ensured especially by international courts (ICs) (Madsen, Chapter 13). The proliferation of ICs began to take shape in the interwar period, and expanded dramatically after World War II and during the Post-Cold War era. Currently, the legal activity of several courts is not evenly 
distributed across the globe: for example, some judgments are more globally widespread than others, as in the case of decisions of the European Court of Human Rights (ECtHR) (which now consist of over 10,000 judgments; in 2011, approximately 160,000 cases were pending before it). Especially since the late 1970s, the ECtHR's activity has contributed to the gradual legitimization of European human rights; this particular evolution "was primarily made possible by the legal-political reflexivity of the small legal elite inhabiting the Court ... who implicitly understood when to hold back and when to push for European human rights'. Nevertheless, the UK's role in favouring extra-European interests and Russia's pressure to regain international power in Europe should affect the ECtHR's strategic space and, therefore, its legitimization strategies. However, the ECtHR, like other ICs, constitutes a 'necessary prerequisite' to guarantee a liberal democracy in Europe.

Moreover, ICs and global quasi-judiciary bodies contribute to the development of GAL by performing a 'regulatory function' (D'Alterio, Chapter 14). There is a directly proportional relationship between the proliferation of global courts (so-called judicial globalization) and judicial regulation, insofar as the latter may be considered the highest stage of development of the former. Courts beyond the state make global rules, by setting standards and creating principles and parameters within a general process of 'judicialization', especially when legislative or codified rules are inadequate or absent. This practice may assume different forms: 'judicial law-making' (with regard to both substantive and procedural rules); 'judicial comity' (the formulation of 'doctrines', based especially on deference mechanisms, that regulate the relations among diverse legal systems); 'legal comity' (which corresponds to the ordering and harmonizing effect that derives from adopting judicial criteria that seek to promote the diffusion of democracy, a greater protection of human rights, and the development of the due process of law at a global level). From this perspective, courts beyond the state can be defined as 'GAL regulators'. Nonetheless, such a definition may raise questions concerning the legitimacy of 'global judicial regulation', the economic interests and political influence relating to the activities of ultra-state courts, the enforcement of their decisions, and the so-called 'judicialization' of GAL.

Civil society also plays a key role in the development of GAL (Bignami, Chapter 15). In particular, civil society contributes to the institutions and practices of liberal democracy at the global level. From this perspective, 'legal and political reforms in the international realm designed to empower civil society carry the benefits promised by the normative theories only if they are also accompanied by the institutions and practices of democracy'. According to the numerous theories of civil society (liberalism, social capital, multiculturalism, cosmopolitanism, effective governance), the global space can be considered an original context within which administrative bodies, such as the WB in the sector of development law, have made some of the most far-reaching reforms in favour of civil society (especially with regard to the WB's Environmental and Social Safeguard Policies). Moreover, the WB largely promotes transparency and the consultation of associations and networks representing civil society at the global level to enhance good governance, accountability and development effectiveness. Other multilateral development banks increasingly follow this direction, giving rise to the inference that other global administrative bodies in the field of international development can learn from the WB's experience. 
Global indicators today constitute a central part of GAL (Infantino, Chapter 16). Developed especially between the 1970s and the 1980s, global indicators have become one of the interesting issues investigated by GAL studies. At the global level, indicators 'have contributed to the circulation of a new form of expertise and new tasks and professions, thus giving rise to ranks of bureaucrats with their own ethos and agenda'. At the same time, a complex network of actors contributes to the production of indicators, with multifarious methodologies capable of 'transform[ing] complex information into numbers, mak[ing] data easily intelligible, facilitat[ing] inter-temporal and inter-unit comparisons ...' Their impact is high, by directing funding or establishing regulatory reforms, and influencing the agenda and working procedures of many subjects. Nevertheless, 'the spread of global indicators has not been universally welcomed': in particular, they should reflect their drafters' implicit domestic and ethnocentric biases; furthermore, a lack of accountability emerges (as demonstrated by the indicators formulated by credit rating agencies). Therefore, the main goal is major compliance with fundamental GAL standards: indicators 'should be transparent about their methodology, give reasons and provide effective review for their choices, allow interested parties to participate in the designing process, and accept accountability for their effects on external actors'.

From the 'vertical point of view', global regimes enter into contact with legal regimes belonging to different levels, by giving rise to relations that involve the EU especially (Vesperini, Chapter 17). The relationship between the EU and global law can be considered from two perspectives: that of the EU's participation in global politics, and that of the relationship between European law and global law. As for the former aspect, there are various models of participation (full membership, observer status, de facto membership, mixed mechanisms); moreover, EU participation in global regimes produces significant effects, as demonstrated by the role performed by the EU within the International Labour Organization (ILO) in 'technical and political domains'. In relation to the latter aspect, the EU participates in numerous global rule-making procedures, such as in the elaboration of the food safety standards drafted by the Codex Alimentarius Commission (CAC). The relationship between GAL and EU law is not yet clear, as emerged in the well-known Kadi saga, in which European judges adopted different solutions by following opposing models, which could be respectively labelled the 'centralized model' and the 'self-contained model'. In all cases considered, however, GAL represents a 'framework', without which multilevel relations between regimes could not be adequately regulated.

GAL also affects 'the lives of people in the Global South', by opening possibilities for social emancipation in terms of both opportunities and challenges (Hernandez, Chapter 18). According to the UN Human Development Index (HDI), 137 national systems belong to the Global South. It is interesting to note that GAL has never distinctively focused on the Global South, although 'GAL's challenges of access to global regulatory bodies, of the goals of these institutions, of the accountability for their actions, and of their influence on domestic authorities, all have a distinct impact in the Global South', especially in relation to democracy. Therefore, GAL could hold significant promise for the Global South, in particular through: the reform of global regulatory governance in a way that takes into account the needs of the Global South; its positive influence over domestic regulatory governance in the Global South; and 
GAL as 'an academic project'. Nevertheless, some scholars affirm that GAL has no emancipatory value, due to its 'indeterminacy'; moreover, the principle of publicness promoted by GAL does not really satisfy the interests of the Global South. The most persuasive promise of GAL is, rather, the 'ius-generative interaction' between legal systems 'in which the rule of law is a credible limit to the unfettered exercise of power', especially on part of the Global North.

From the above-mentioned perspective, the emergence of a 'GAL of development cooperation' is remarkable indeed (Dann, Chapter 19). Despite the existence of multiple theories on the notion of 'development', development cooperation is based on common aspects: the organization of transfers; a cyclical process, articulated in numerous administrative procedures; and multilevel legal sources. In light of these features, it appears particularly advisable to suggest principles for the 'GAL of development', relating to the relationship between individuals and administrative powers in this field, as well as collective autonomy, protection of human rights, efficiency and accountability. It is a sector within which, as testified by the growth of institutional competition and the increase of alternative types of financial sources, together with the diversification of the formats used to transfer funds, some important GAL instruments have circulated, such as conditionality and safeguards clauses, indicators, and complaint mechanisms relating to the implementation phase. The evolution of these instruments in development cooperation is 'a mirror of the rise of and challenge to Western thought' and, in this sense, allows us to better understand the more general transformation of the global legal order.

As regards the relationship between GAL and national systems, many GAL norms operate as legal sources for national administrations by affecting national legal systems to a great extent (Chiti, Chapter 20). Several variables - which differ from case to case - characterize this phenomenon, although a meaningful classification is not possible within the limited space available here. For instance, in the case of global military operations, domestic agencies are not regulated by GAL norms but by a plurality of national and non-national norms, which give rise to a GAL discipline; in the case of the WTO, global law directly establishes standards and checks for domestic agencies, by taking the form of a set of principles and rules, which may be both binding and non-binding; finally, in the European Convention on Human Rights (ECHR) system, administrative standards have a stronger rights-based nature and are addressed to both domestic administrations and individuals, although their direct effect is often complemented by supremacy vis-à-vis conflicting national legislation. These cases show that 'GAL may grow in scope precisely because it challenges, in a discreet manner, the power of states to operate as screens between GAL norms and domestic laws'. This 'operationalization' of global norms in domestic legal orders contributes to a process of gradual convergence, although it does not sustain 'the claim that GAL will actually be able to guarantee the stability and legitimation of the global administrative space'.

The gradual erosion of state sovereignty is remarkable especially in the context of international security policies, which are characterized by the shift of functions traditionally within the purview of individual states to the global level (Dunlop, Chapter 21). The main international security operations are UN-led peacekeeping operations, UN-authorized actions by regional organizations or willing states, and 
autonomous peacekeeping operations executed by regional organizations. Many tensions affect the coordination between the Security Council and the regional organizations engaged in international security operations, especially concerning the lack of competence of regional and domestic courts to review UN Chapter VII resolutions of the Security Council, when judicial challenges are brought against wrongful acts committed in the course of international security operations. Special concerns regard the UN Security Council's Al-Qaida sanctions regime, which suffers from several 'accountability gaps' that could be filled under pressure from states and supranational networks. Moreover, the Security Council is developing practices in the areas of health (notably pandemics), transnational organized crime and climate change, thus showing an ever-expanding field of its competence and, at the same time, feeding further concerns as to its willingness and capacity to respond to calls to strengthen its accountability frameworks.

Nevertheless, the future of state sovereignty in the global space is not truly challenged (Benvenisti, Chapter 22). On the one hand, global governance bodies public, private and mixed - limit the state's traditional powers to adjudicate and enforce (e.g. in relation to the exercise of violence); moreover, the rise of common global problems (global terrorism, human trafficking, climate change, etc.) and the significant expansion of global trade require collective actions and responses. The result is an erosion of the traditional constitutional checks and balances that may be found in many democracies, as 'the traditional premise that sovereignty as freedom from can guarantee its citizens the freedom to' is shattered. On the other hand, states can act proactively in response to global regulation or the lack thereof, also by providing for the judicial review of global acts, "using their "gatekeeping" opportunity to reject global policies that they consider to be incompatible with domestic law'. Furthermore, the integration of states into the global regulatory space appears to be less advantageous for poor countries than for strong ones, although the latter should have an interest in ensuring the stability and welfare of weaker states, in managing migration flows and in reducing military threats, etc. From this perspective, states remain the 'key participants in the robust exchange between global, regional and local policymakers'.

Therefore, there is an erosion of state sovereignty; at the same time, the role of states in the global space is not fully challenged. Indeed, the fact is that states must deal with several 'paradoxes' of globalization, and their role has significantly changed over the last few years (Cassese, Chapter 23). This is due to at least three aspects. First, in the global space, power is shared between national and supranational rulers, as may be seen in the realms of environmental protection, oil and gas exploitation in the Arctic, and global health security. These are global problems that simply cannot be solved at a national level alone. Second, there is a deep fragmentation of national governments: these are masters but also servants; they engage in contradictory courses of conduct; and they combine with global subjects, thus losing their unity. In this sense, global governance has a 'marbled structure', although the divide between the domain of economics and that of politics is still strong. Finally, given the absence of a supreme authority (a 'global government') or hierarchy, global space is characterized by transnationalism, transactionalism, multilevel procedures, different types of global administration and sectoralism, although some general global principles may be recognized. From this perspective, the 'idea of governing the world' is now outdated - 
not because it is 'becoming yesterday's dream', but because it recalls the Westphalian approach, while it is now necessary to think in terms of a global 'common system'.

The analysis of GAL ends with particular attention being devoted to the 'globalization debate' (Howse, Chapter 24). Globalization is 'a magnet for a range of deeply felt hopes and fears, and still produces intense polemics "for" and "against". Especially at the end of the Cold War, market liberalism triumphed, with the inextricably intertwined effect of openness to globalization. It raised a globalization movement, but also an anti-globalization movement (the latter defending the traditional state against 'globalization'). Currently, however, the (first or classic) globalization debate is over: that debate focused on whether the state was weakened by globalization; but now the real issue is how the state has been 'remade'. Moreover, the problems highlighted by the anti-globalization movement today could not be solved by individual states, as they concern the protection of global values (e.g. fighting climate change, protecting biodiversity, etc.). Global institutions are now capable of balancing different values, some of which are also traditionally associated with 'anti-globalization' (human rights, sustainable development, etc.). For these reasons, the 'feeling of alienation and disempowerment' at the national level cannot dismantle the role of international institutions; quite to the contrary, 'it should be dealt with by renewing domestic political institutions and finding new ways to encourage political participation'.

In the above-mentioned context, figures and communities of global lawyers emerge (Vauchez, Chapter 25). Cosmopolitan politicians of law, international peacemakers, middlemen of Europe's regional integration, human rights activists, business professionals and transnational judicial diplomats are the main actors in the global legal landscape. Nevertheless, the current fragmentation contributes to the formation of a variety of poles at the global level - 'constitutional/international courts, private/public bodies, market/human rights, legal scholars/private practitioners, etc.' . In particular, the proliferation of ICs strengthens fragmentation and segmentation among lawyers: 'there is no "court" without a (more or less stable) world of professionals ranging from law clerks, registrars, lawyer-linguists to a variety of "repeat players" connected to the court (lawyers, state and EU institutions' legal advisers, and law professors)'. However, these legal communities are interlocking networks with overlapping memberships, which show a certain degree of interdependence. The main goal is to open these legal communities to alternative views, silenced voices and alternative reasonable explanations, by overcoming the professional and doctrinal captures and the representativeness gap affecting them.

Indeed, a particular community of 'global lawyers' is represented by GAL scholarship (Casini, Chapter 26). The first appearance of the term 'Global Administrative Law' in a legal essay dates back to 2002-2004, although 'phenomena' of administrative law at international level may already be found - as broadly outlined above - in the late nineteenth century. The genesis of GAL scholarship derives from the 'intuition' that global governance could be explained through an administrative law - but also a multidisciplinary - lens. Its development deals especially with 'the search for a balance between (1) the normative and the realistic dimensions of GAL, (2) case studies and general theory, and (3) legal background and other disciplines'. In particular, GAL scholarship proposes new classifications of international organizations and highlights the procedural dimension of global administration, also by paying particular attention 
to inter-institutional relations. Historically, European scholars have focused the most on GAL, although in recent years, GAL scholarship has spread across the world (Latin America, Africa, Asia and Australia) - which has given rise to both advantages and disadvantages (especially relating to GAL labelling and to an underestimation of GAL's complexity). However, an assessment of the last ten years shows that GAL scholarship has reached a high degree of 'maturity': the very production of a 'GAL Handbook' is one of the strongest indicators in this respect. 
Sabino Cassese and Elisa D'Alterio - 9781783478460 Downloaded from PubFactory at $\odot 4 / 26 / 2023$ 12: 06 :35PM via free access 